\title{
超音波生体指センサによる指荷重と表面性状評価の試み
}

竹内 彰敏*1

\section{An attempt to evaluate finger load and surface texture by biometric finger sensor using ultrasonic method}

\author{
Akitoshi TAKEUCHI ${ }^{*}$ \\ ${ }^{* 1}$ School of System Engineering, Kochi University of Technology \\ 185 Miyanokuchi, Tosayamada-chou, Kami-shi, Kochi 782-8502, Japan
}

Received: 9 August 2017; Revised: 10 October 2017; Accepted: 4 December 2017

\begin{abstract}
The potential of an ultrasonic biometric finger sensor to evaluate the finger load and surface texture in contact opposition was investigated under the range of quasi-static load and low sliding speed. The ultrasonic probe, which has a respective vibration element for reception and transmission, attached to the nail plate has a transducer $5 \mathrm{~mm}$ in diameter with $5 \mathrm{MHz}$ center frequency. The reflection echo ratio $H_{l}$ from the nail bed is reduced with increment of nail bed stiffness (acoustic impedance) due to increasing finger load $W$. In contrast, the reflection echo ratio $\mathrm{H}_{2}$ from the finger-pad is increased with increment of finger load since the amplitude of interference wave reflected from the finger-pad is increased due to the phase decrement of the reflected wave from there by flattening of the finger pad. Therefore, the potential for the estimation of finger load $W$ using the echo ratio $H_{1}$ or $H_{2}$ was cleared. Additionally, it becomes possible to evaluate the surface texture in contact opposition since the finger-pad echo ratio $\mathrm{H}_{2}$ is strongly affected by local displacement on finger-pad. Since the nail bed echo ratio $H_{1}$ during catalyzed migration of the finger depends on only finger load without being influenced by the texture of the opposition surface, the potential for the substitution of tactile impression of the person by the simultaneous observation of $H_{l}$ and $H_{2}$ became clear.
\end{abstract}

Keywords : Biometric finger, Ultrasonic method, Interference, Finger pad, Finger load, Surface texture

\section{1. 緒言}

人の触覚を代替する種々の触覚センサの開発が盛んに行われている，感圧導電ゴムの利用，電極間の容量変化 の検知，巧妙な音響共鳴触覚素子，そして，透明なゴム製半球でのレーザー光の反射を利用するもの，位相シフ 卜式発振回路を用いた PZT 触覚センサ等多くのセンサが挙げられる (吉海他, 2002), (Omata and Terunuma, 1992), (Takeuchi, 2013)，（小山他, 2016). 例えば，光学式触覚センサは，透明弾性体で構成された入力デバイスとカメ ラ部から構成され，弾性体に加えられた 3 次元のカベクトルの分布を実時間で計測している（Kamiyama et al., 2005).

しかしながら，それらの触覚センサは，指の形や皮下組織を真似た物や，感覚受容器を歪ゲージや静電容量に より模倣したセンサであり，実際の指を用いて，対象物との接触を評価するものではない（Hyung et al.,2008）, (Mukaibo et al., 2005)，（Ohka et al., 2005)．人の指そのものを利用したセンサの場合，一人一人異なる特性を持 つ個人の指での実際の触動作時の官能評価，との対応が可能になる．それゆえ，例えば，化粧用のクリームを肌 に延ばす際の指荷重のかかり具合と使用感の関係を従来にない正確さで評価できる (Kakizawa et al., 2013). また, 製品表面の触り心地の官能評価結果と，生体指センサで計測される触動作時の情報との対比から，触り心地の良 い表面の創出や表面性状の改善に寄与できる情報が得られる可能性も高い.さらに, 指の感覚機能を失った人や, 加齢により触感覚の鈍った人に対する感覚の代替も期待できる.

No.17- 00348 [DOI:10.1299/transjsme.17-00348], J-STAGE Advance Publication date : 12 December, 2017

${ }^{* 1}$ 正員, 高知工科大学システム工学群（テ782-8502 高知県香美市土佐山田町宮ノ口 185）

E-mail of corresponding author: takeuchi.akitoshi@kochi-tech.ac.jp 
そのような生体指を利用した指荷重センサには，例えば，指の爪側に取り付けた赤外線フォトダイオードによ り，相手面接触時の爪床の血流量変化を計測するものや（Mascaro and Asada, 2004），(安藤他，2003），爪に貼り 付けた複数枚の歪ゲージにより荷重の方向も含めた評価の可能性を示した研究 (前野他, 2000), (白井他, 2005), そして，負荷に伴う指幅の変位を歪ゲージで測定するセンサ等がある（Nakatani et al., 2011）。しかし，例えば一 定指荷重の下で，数十ミクロンの粗さ面上を指が滑るときには，粗さ面との接触により指腹は逐次変形するもの の，その変形は爪床には及び難い，このため，一定の指荷重を受ける爪床の血流はほとんど変化せず，相手面の 粗さ情報の取得は難しいと考える.ややり, 相手面と指腹との接触部での情報を直接捉える観測法が必要になる.

本研究では, 赤外線フォトダイオードや歪ゲージの代わりに, 超音波センサを人の指の爪甲部に設置して測定 される，爪床や指腹部からの反射エコーに着目し，指にかかる荷重や，相手面の表面性状の違いの評価を試みて いる．本報では，指荷重の定量測定法につき検討すると共に，荷重と表面性状との同時測定についても調査し， 本センサシステムによる, 人の触感評価の一部代替の可能性についても検討する.

\section{2. 人の指の構造と実験した指の特性}

図 1 に人の指腹部軟組織の断面模式図を示寸 (Vallbo and Johansson, 1984).人の指腹部は, 下方に示寸模式図 （断面）のように，表皮，真皮，皮下組織からなる．表皮の表面には指紋があり，指紋直下の表皮と真皮の境界 には，真皮乳頭と呼ばれる突起が 2 列に並んでいる，速度センサとして機能するマイスナ一小体は，それら突起 の谷間に位置しており，変位センサの役割をするメルケル小体は，乳頭部先端付近に存在している．一方，皮膚 深部あるいは皮下脂肪層には，変位センサの役割を果たすルフィニ小体や，加速度センサとして機能するパチニ 小体が存在する.

本研究では, 上述した各受容器の機能を代替し, 指に作用する荷重（力）や触動作時の触感覚（表面性状）を 評価可能な生体指センサの開発を目指している。ここでは, 主に, メルケル小体での変位センサ (圧覚) 機能, マイスナー小体での皮膚振動検知機能を代替して, 指荷重や表面性状を評価できる, 超音波生体指センサの可能 性について検討寸る.

ところで, 指組織を伝播する超音波は, 指に作用する荷重により決まる, 指腹の変位や接触による平坦部の大 きさに依存して反射すると考えられる.図 2 は, 後に述べる図 4 の環状動力計の平らな天板に, 指腹 (半径約 $7.5 \mathrm{~mm}$ ) を静的に押し付けて測定した, 指荷重 $W$ と指腹の変位 $\delta$ との関係である. 各荷重での変位は爪に付けたマーカー とハイトゲージにより, 接触面積は朱肉を付けた指腹を天板に貼り付けた白紙に押し付けることによって求めた. 例えば, 弾性体の指腹（半径 $r$ の球面と仮定）と平面が接触する場合の変位 $\delta$ と荷重 $W$ との関係は, 指腹の縦弾 性係数 $E$ が平板に比べて極めて小さいとした場合には，以下で与えられる（Timoshenko and Goodier, 1970）.

$$
d_{M}=0.77\left(E^{2} r\right)^{-1 / 3} W^{2 / 3}=\alpha_{1} W^{2 / 3}
$$

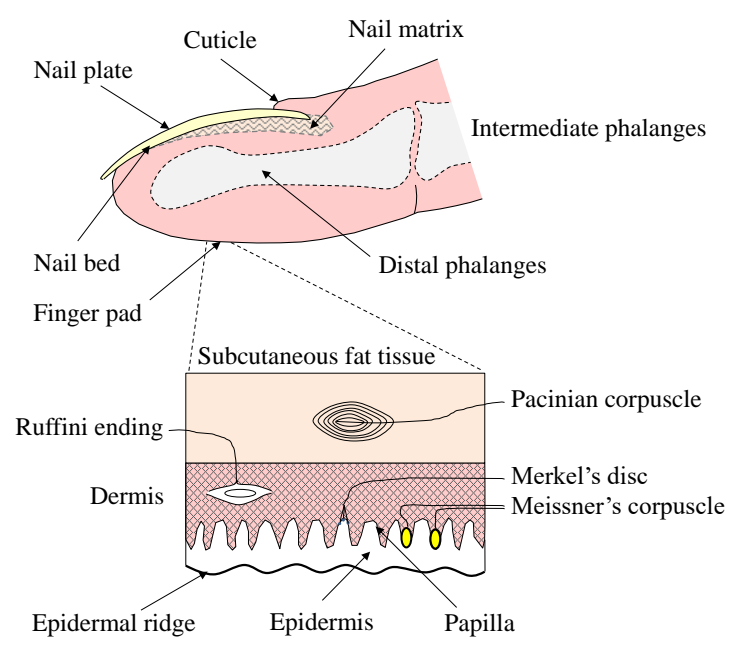

Fig. 1 Sectional schematic view of the finger pad soft tissue 


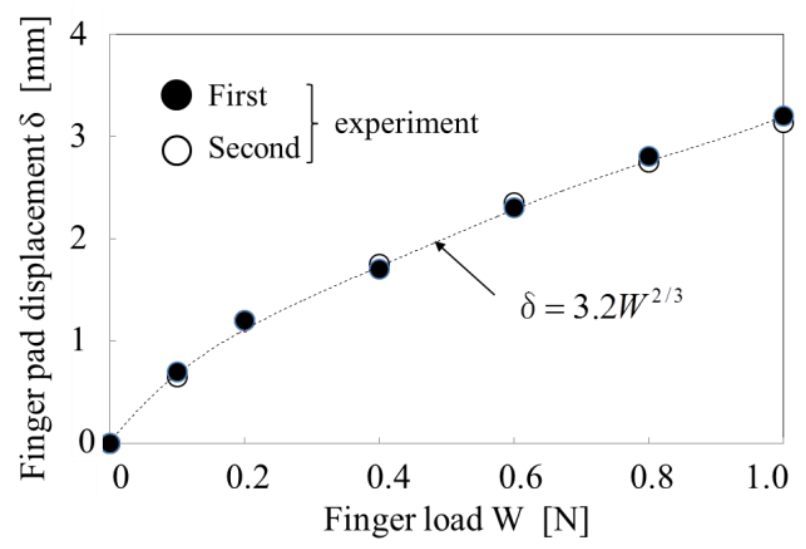

Fig.2 Relationship between finger load W and displacement $\delta$ of the finger pad.

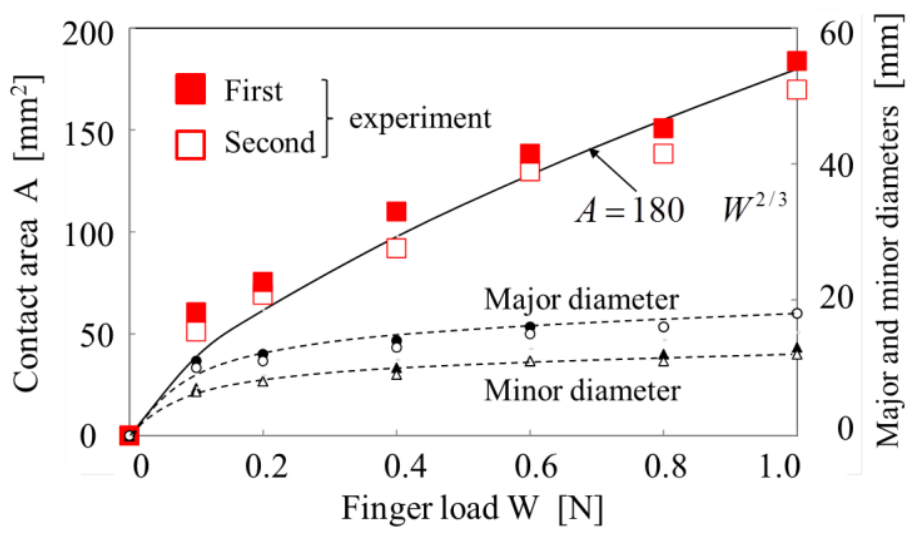

Fig. 3 Contact area A which was calculated from the major and minor diameters of the ellipse when a finger pad touched the flat plate.

$W=1 \mathrm{~N}$ での指腹変位が $\delta=3.2 \mathrm{~mm}$ となる $\alpha_{l}$ の值 $\left(\alpha_{l}=3.2 \mathrm{~mm} / \mathrm{N}^{2 / 3}\right)$ を用いて計算した, 指腹荷重 $W$ と指腹の変位 $\delta$ との関係は，図中の破線で示すように，実駼結果とほぼ一致する。ちなみに，上式から推定される指腹の縦弾性 係数は， $4.3 \times 10^{4} \mathrm{~Pa}$ であり，一般的に知られている皮下組織の值 $3.4 \times 10^{4} \mathrm{~Pa}$ に近い.

図 3 は，負荷により指腹が接触した際の楕円の長径と短径から計算した接触面積 $A$ を示したものであるが， 2 回の実験結果はほぼ等しく, 再現性が確認できる. 上と同様に, 指腹を半径 $r$ の球面と仮定して, 接触面積 $A$ と 荷重 $W$ との関係を求めると, 以下のようになる。

$$
A=2.43(r / E)^{2 / 3} W^{2 / 3}=\alpha_{2} W^{2 / 3}
$$

$W=1 \mathrm{~N}$ での指腹接触面積が $A=180 \mathrm{~mm}^{2}$ となる $\alpha_{2}$ の值 $\left(\alpha_{2}=180 \mathrm{~mm}^{2} / \mathrm{N}^{2 / 3}\right)$ を用いて計算した, 指腹荷重 $W$ と指腹 の接触面積 $A$ との関係もまた，実験結果とほぼ一致する．以上示したように，一定荷重で十分な保持時間を有す る場合の指の変形は，ほぼ弾性的である．前述のように，超音波の反射（エコー高さ）が，指腹の変位や平たん 部面積に依存するなら, エコー高さは指荷重 $W$ の $2 / 3$ 乗に比例して増加するはずであるが, このことについては, 第 4 章の図 10 で検討寸る.

\section{3. 生体指センサの測定系}

図 4 に生体指センサを含む計測システムの概略を示す，指荷重の測定は，図 5 に示す治具を用いて爪甲部に取 り付けた超音波探触子で行う。使用した超音波探触子は，振動子径 $5 \mathrm{~mm}$ （探触子外形 $7 \mathrm{~mm}$ ), 中心周波数 $5 \mathrm{MHz}$ で，送信用と受信用に別々の振動素子を有しており，探触子の極近傍に位置する爪床（爪甲と密着した表皮から 


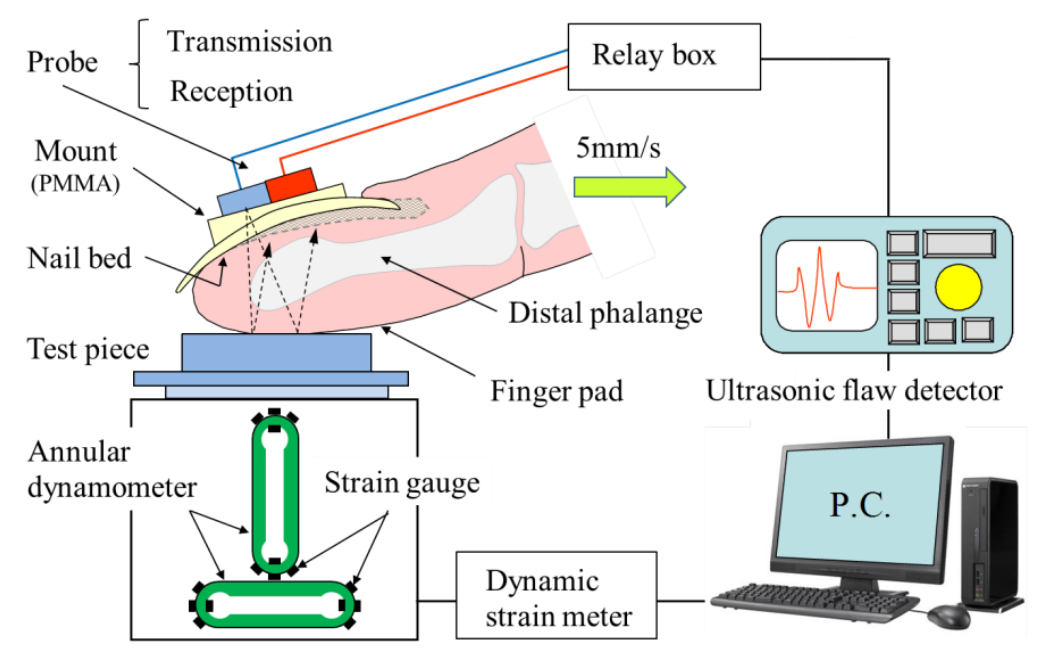

Fig. 4 Schematic diagram of measurement system including biometric finger sensor.
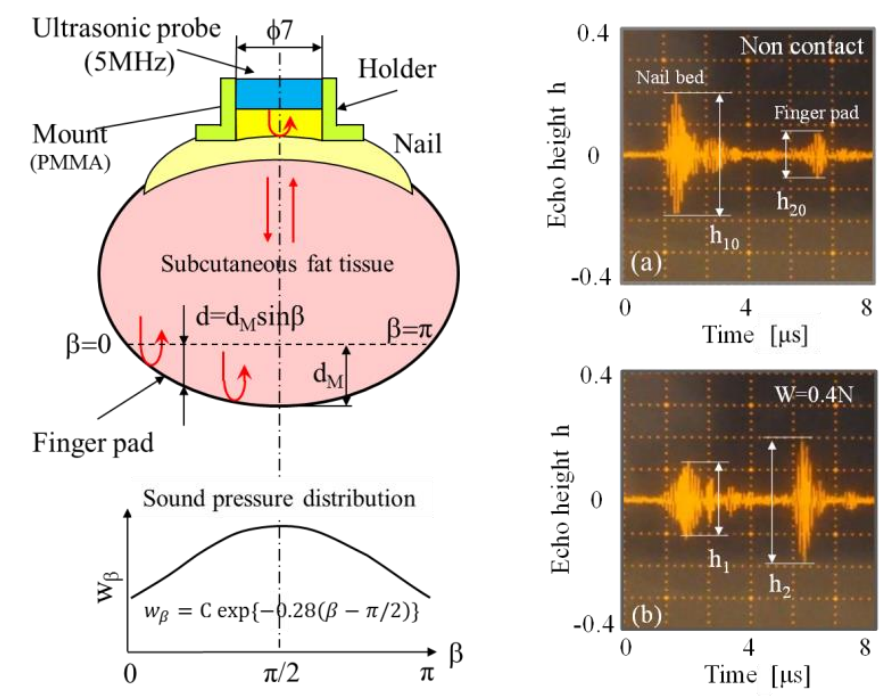

Fig. 5 Measured reflection echo height $h$ and schematic view of the sound pressure distribution in effective region. A part of the pulse ultrasonic wave entered from the transmitting element is reflected in response to the stiffness of the nail bed depending on the finger load. The remainder of the wave propagates to the finger pad and reflects at there. The nail bed echo height $h_{10}$ is higher than the finger pad echo height $h_{20}$, in the non-contact case. However, as shown in under side right figure, the finger pad echo height $h_{2}$ increases and becomes higher than reduced nail bed echo height $h_{l}$ when the finger pad touches a flat plate. Incidentally, the Gaussian distribution shown in under side left figure is supposed in estimation of finger pad echo ratio $H_{2}$ in Chapter 5. Phase $2 d$ is difference of round-trip propagation distance from the end of effective region ( $\beta=0$ and $\pi$ are region ends).

なる）からの反射波も感度良く観測できる。爪への探触子取付け台（PMMA 製）の設置には付け爪用の接着剤を 用い, 台への探触子の設置には専用の音響カプラントを用いている. なお，取り付け台と爪とを合わせた厚さは， 約 $2 \mathrm{~mm}$ である. 送信用素子から入射されたパルス状の超音波の一部は，負荷に依存した爪床部の皮膚剛性に応 じて反射し, 残りは, 指向角に応じて広がりながら, 皮下組織や骨を透過し（音響的性質が異なる末節骨部では, 一部が反射して散乱減衰が生じる), 指腹部に到達する. 到達した音波はそこで反射して探触子へと戻る. 観測さ れる超音波のエコー高さは，上述した爪床からの音波の透過具合や，相手面との接触に応じて変位する指腹（図 5 参照）の各部位からの反射波の干渉に依存寸ると考えられる（詳細は 5 章で述べる）。このため, 荷重の負荷・ 除荷過程での指腹の変形や，そこでの指荷重の定量的なその場観測ができる可能性がある，なお，指腹に作用寸 


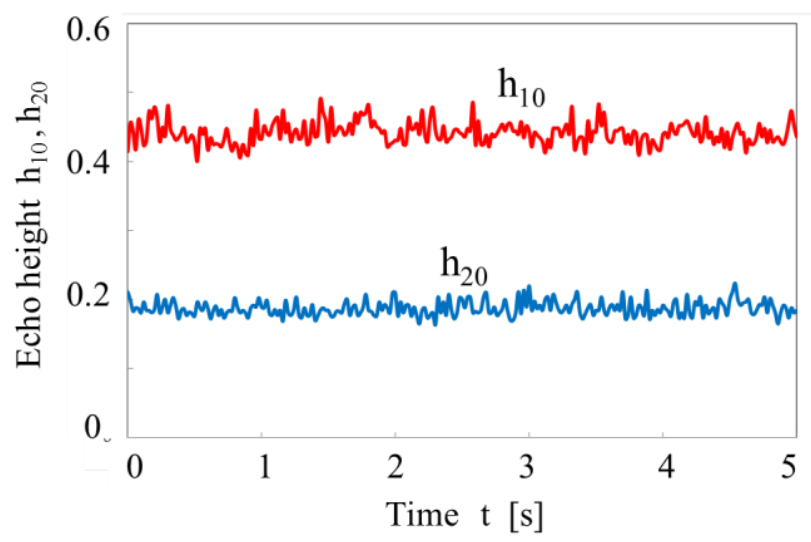

Fig. 6 Behavior of nail bed echo height $h_{10}$ and finger pad echo height $h_{20}$, when the forefinger which mounted a probe is vibrated about $\pm 10 \mathrm{~mm}$ with a period of about $3 \mathrm{~Hz}$.

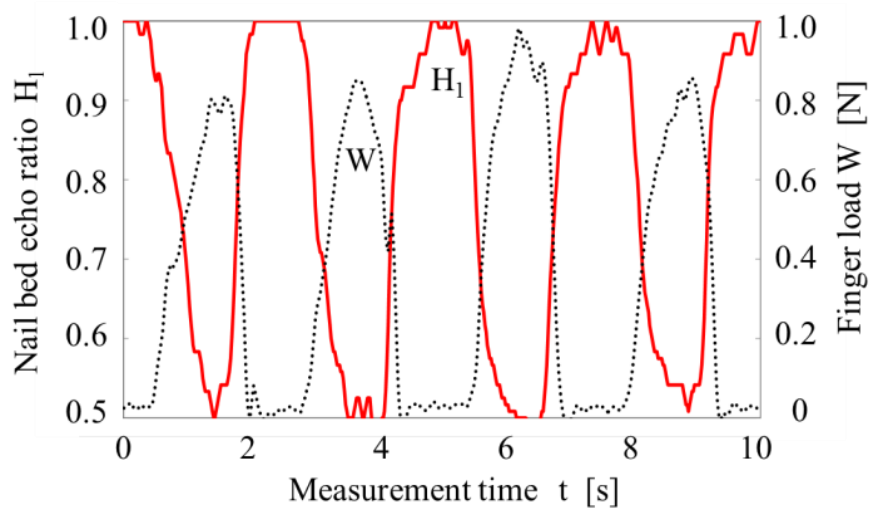

Fig. 7 Behavior of finger load $W$ and nail bed echo ratio $H_{l}$, when a finger pad is pressed to a flat and smooth top plate of tactile impression equipment and is separated from it with about $0.4 \mathrm{~Hz}$.

る実際の荷重は, 図 4 左下の環状動力計により計測され, 爪床や指腹からの反射エコー高さとの較正值の取得や, エコー高さから推定される指荷重との相関を得る際に用いられる.

さて，指に負荷される荷重や，触動作による相手面の性状評価は，上述した，爪床や指腹からの反射波のエコ 一変動の観測を基に行う。図 5 右側の写真は，それら双方からの反射波を示す，超音波探傷器画面である．この 場合，(a)に示した非接触時の爪床エコー高さ $h_{10}$ は，指腹エコー高さ $h_{20}$ の倍近い值を示している．しかし，指腹 が接触すると，(b)に示すように，指腹エコー高さ $h_{2}$ は増加して，爪床エコー高さ $h_{1}$ より高くなる. この時の爪 床エコー高さは非接触時の $2 / 3$ 近くまで低下するのに対し, 指腹からの反射エコーは非接触時の 3 倍近くまで増 加している.

ここでは，アクリルマウントと爪との接触を含む探触子系の取り付け状態や，伝搬経路での音波の減衰の影響 を無くするために，接触時のエコー高さを非接触時のエコー高さで規格化したエコー比， $H_{1}=h_{1} / h_{10}, H_{2}=h_{2} / h_{20}$ を 定義する．なお，評価に用いるエコー高さは，それぞれの反射波内での最大のエコー高さである.

ところで，図 6 には，探触子の取り付け状態の 5 秒間の安定性の評価結果を示してある. 非接触状態の人差し 指に取り付け， $3 \mathrm{~Hz}$ 程度の周期で指を $\pm 10 \mathrm{~mm}$ 程度振動させた場合の爪床・指腹エコー高さ $h_{10}$ と $h_{20}$ は, 計測中 一定の值を維持し，指の振動に伴う周期的な変動は認められない. なお，同実験は 1 分間継続されたが，その際 のエコー高さのシフトは，2\%程度と小さかった。 


\section{4. 指荷重 $W$ と床エコー比 $H_{p}$, 指腹エコー比 $H_{2}$ の関係}

図 7 は，平滑で平坦なアルミ製の天板を有する触感計（図 4）に，上記の超音波探触子を装着した指の腹部を $0.4 \mathrm{~Hz}$ 程度で押し付けたり離したりしたときの, 指荷重 $W$ と爪床からの反射エコー比 $H_{1}$ の挙動を示したものであ る. $W$ と $H_{1}$ は逆位相の関係にあり, 指荷重が大きいほど爪床部の剛性が増し，そこからの音波の透過割合が増 えるため, エコー比 $H_{l}$ は非接触時の值の 1.0 より低くなると考えられる. そのような負荷・除荷過程での両者の 関係は図 8 のようになる．荷重と共に爪床部の剛性が増寸負荷過程（赤丸印）での両者の相関は，荷重が解放さ れて皮下組織の粘性的性質が現れ易くなる除荷過程の場合（白丸印）より高く, 相関係数は $R=0.96$ を示す.

図 9 は図 7 と同じく, 触感計の天板上で, $0.4 \mathrm{~Hz}$ 程度で荷重を増減させた場合に観測された，指荷重 $W$ と指腹 エコー比 $H_{2}$ の変動を示したものであり, 反射エコー比 $H_{2}$ は指荷重 $W$ と共に増している. この場合の相関係数は, 図 10 中に示寸ように $R \geqq 0.95$ と高い值を示し，爪床（図 8）同様，負荷過程での相関が高い．ところで，同図中 には，指腹エコー比が指荷重 $W$ の $2 / 3$ 乗に比例するとして求めた $H_{2}$ の挙動を示してある. そこでの定数項は, $W=0 \mathrm{~N}$ で $H_{2}=1.0, W=1 \mathrm{~N}$ で $H_{2}=5.2$ の実験点と一致するように定めた．なお，非接触時（W=0N）の指腹のエコー 高さは, $h_{2}=h_{20}$ となるため, そこでの指腹エコー比 $H_{2}=h_{2} / h_{20}$ は, $H_{2}=1.0$ となる. 計算結果は, 実駼結果とほぼ一 致しており, 第 2 章で予測したように， $H_{2}$ は指腹の変位とそこでの平坦部の大きさに依存して変動すると考える ことができる.

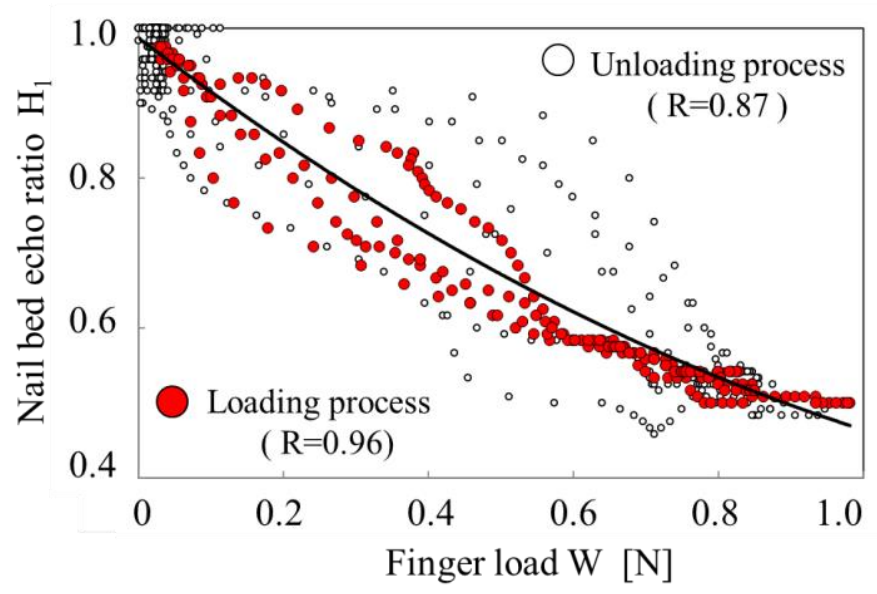

Fig. 8 Behavior of finger load $W$ and echo ratio $H_{l}$ reflected from the nail bed. $H_{l}$ has an antiphase relationship with $W$ and the echo ratio $H_{l}$ is below 1.0 because the transmission rate of the ultrasonic wave increases with finger load. The correlation in loading process that the stiffness of the nail bed portion increases with load is high (correlation coefficient $R=0.95$ ).

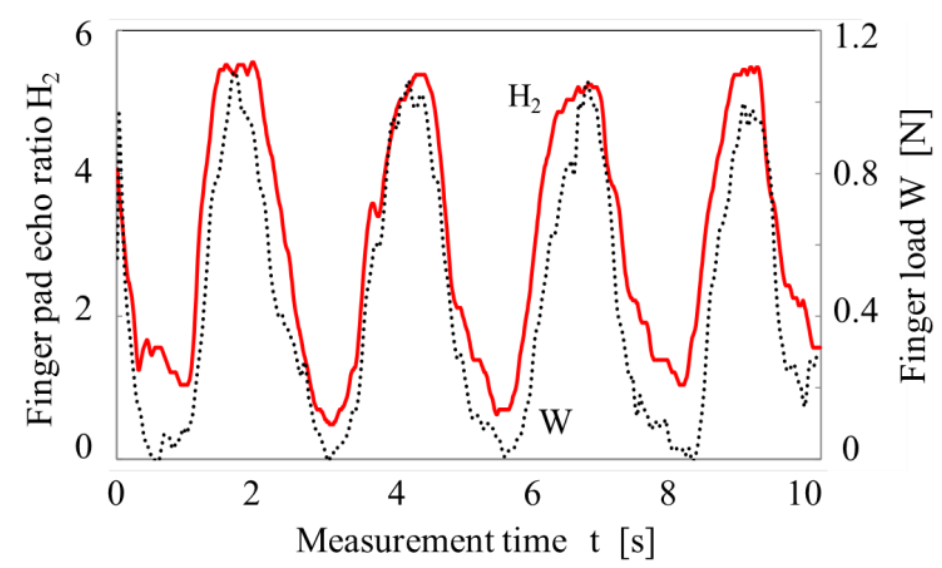

Fig. 9 Variation of finger load $\mathrm{W}$ and finger pad echo ratio $\mathrm{H}_{2}$, when a finger pad is pressed to a top plate of tactile impression equipment and is separated from it with about $0.4 \mathrm{~Hz}$. 


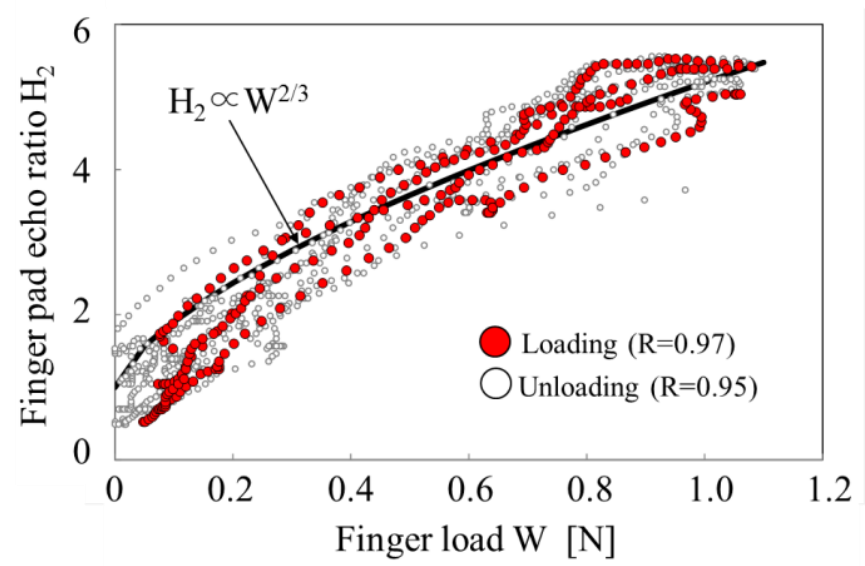

Fig. 10 Relation between $W$ and $H_{2}$ under loading and unloading process. Finger pad echo ratio $H_{2}$ increases with increment of displacement of finger pad due to finger load $W$. A strong correlation appears in the loading process. Behavior of calculated finger pad echo ratio $\mathrm{H}_{2}$ shown in a solid line, which supposes the elastic deformation $\left(H_{2} \propto W\right)$, accords with observation result almost.

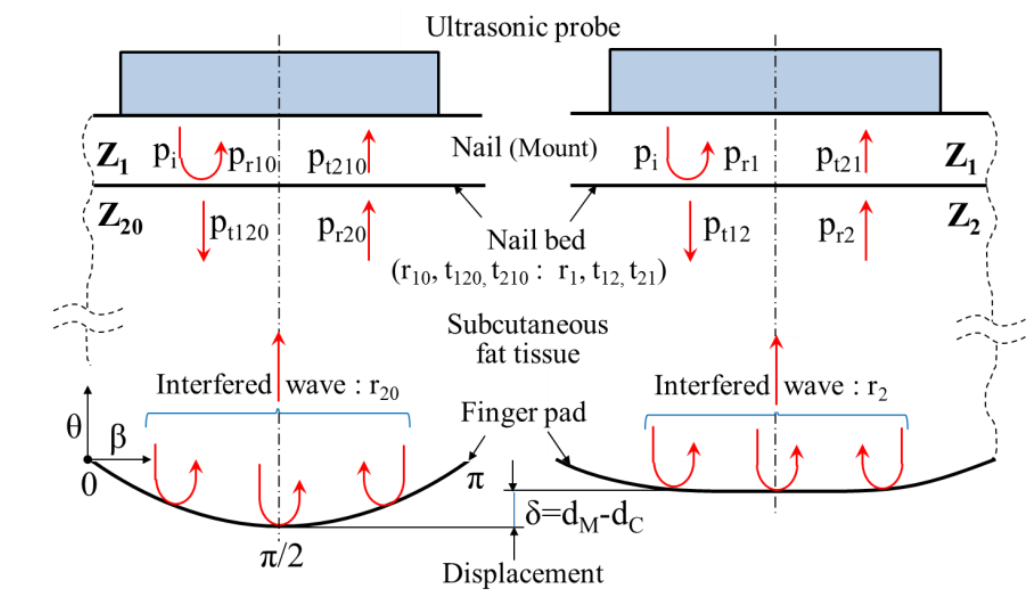

(a) Non contact

(a) Loading

Fig. 11 Simplest two-dimensional reflection model. The $p_{i}, p_{r}$, and $p_{t}$ are the sound pressures of incident wave, reflected wave at each boundary and transmitted wave through boundary. The $r_{1}, r_{10}$ and the $r_{2}, r_{20}$ are the reflection coefficients of sound pressure at the nail bed and the finger pad. The $t_{120}, t_{210}, t_{12}, t_{21}$ show the sound pressure transmissivity at the nail bed portion.

\section{5. 爪床での音波の透過と指腹変位を考慮した指腹エコー比 $H_{2}$ の検討}

4 章で述べた $\mathrm{H}_{2}$ の荷重依存性を明らかにするために，指腹の皮下組織部での減衰や末節骨での散乱減衰を考慮 しない，最も単純な 2 次元反射モデル（図 11）を考える. 図中の $p_{i}$ は爪床一入射する波の音圧（振幅）， $p_{r}$ は反 射波の音圧で，添え字の 1 は爪床境界での反射，2 は指腹から反射波して爪床境界に到達した波を示す． $p_{t}$ は爪 床境界からの透過波音圧で，添え字の 12 は爪から指腹へと伝搬する波の透過，21 は指腹から爪床境界に到達し た波の透過を，そして０は指腹が非接触の状態を示している．また， $r_{10}$ と $r_{1}$ や， $r_{20}$ と $r_{2}$ はそれぞれ，爪床境界 部と指腹部での音圧反射率を, $t_{120}, t_{210}, t_{12}, t_{21}$ は爪床部での音圧透過率を示す.

さて, 図 11 の簡易モデルでの受信エコーは, 往復通過率 $T$ に依存すると考えられる. 例えば, 指腹が非接触 状態においては，往復通過率 $T_{0}$ に依存して,

$$
T_{r 0}=T_{0} r_{20}=\left(1-{r_{10}}^{2}\right) r_{20}
$$


で与えられる（社団法人日本非破壊検查協会，1990）。また，第一近似として，後述する指腹部での反射波の干渉 を考慮せず，指腹と空気の境界では全反射をすると考えると， $r_{20}=1$ と仮定できる. 一方，指腹が接触（変形）す る場合においては，往復通過率を $T$ として，

$$
T_{r}=\operatorname{Tr}_{2}=\left(1-r_{1}^{2}\right) r_{2}
$$

で与えられる. ところで, 同一指荷重下での指腹部音圧反射率 $r_{2}$ は, 接触相手材の材質にほとんど影響されず, 発泡スチロールや硬質ウレタン等の低密度（空気に近い）での值とほぼ同じであった．このため，非接触時と同 様, 指腹部での反射波の干渉を考慮しない場合は $r_{2}=1$ と仮定できる. したがって, 前述した指腹エコー比 $H_{2}$ は,

$$
H_{2}=\frac{T}{T_{0}}=\frac{1-r_{1}^{2}}{1-r_{10}{ }^{2}}=\frac{t_{12} t_{21}}{t_{120} t_{210}}=\left(\frac{Z_{1}+Z_{20}}{Z_{1}+Z_{2}}\right)^{2} \frac{Z_{2}}{Z_{20}}
$$

で与えられ，爪床境界での音圧透過率に依存寸る.ただし， $Z_{1}$ は爪部， $Z_{20}$ は非接触時の爪床部， $Z_{2}$ は接触時の爪 床部の音響インピーダンスである。ただし，爪部は硬質（PMMA 程度）であるため，接触・非接触に関わらず，

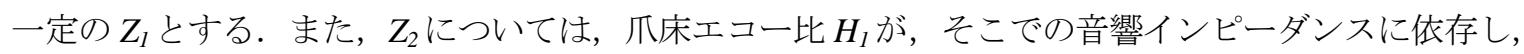

$$
H_{1}=\frac{r_{1}}{r_{10}}=\left(\frac{Z_{2}-Z_{1}}{Z_{1}+Z_{2}}\right)\left(\frac{Z_{1}+Z_{20}}{Z_{20}-Z_{1}}\right)
$$

で与えられることから, 図 8 で示した各荷重 $W$ での $H_{l}$ に対する推定值を採用した. ちなみに, $Z_{l}$ にはPMMAの 值 $\left(=3.2 \times 10^{6} \mathrm{~kg} / \mathrm{m}^{2} \mathrm{~s}\right), Z_{20}$ は生体軟組織に対する一般的な值 $\left(=1.65 \times 10^{6} \mathrm{~kg} / \mathrm{m}^{2} \mathrm{~s}\right)$ を仮定した. 図 12 中には, 計 算された $T / T_{0}$ の挙動を破線で示してある. 確かに, 荷重と共に $H_{2}$ も増加するが，その程度は小さく，負荷に伴 う爪床境界からの透過率の増加で， $H_{2}$ の観測結果（図 10）を説明することは難しい.

指荷重負荷時の指腹エコー比 $H_{2}$ には, そのような爪床からの音波の透過量に加え, 負荷時の指腹の変位に伴う 指腹各部からの反射波の位相差の減少が大きく影響していると考えられる. そこで, 前述した簡易モデル (図 11) において，その影響を検討する．なお，指腹へは連続的な平面波の入射を仮定するとともに，入射音圧が高い(工 コー高さへの寄与が大きい）指腹中央 $(\beta=\pi / 2)$ 付近での指腹の傾斜は小さいので, 反射に対する傾斜の影響を考 慮しないとした近似的な取扱いを行う。

反射波の位相差の影響は，図 11 中の指腹部での音圧反射率 $\left(r_{2}, r_{20}\right)$ に現れる．これらの影響を考慮した場合 の $\mathrm{H}_{2}$ は，式(3)〜式(5)を基に，以下のように求まる.

$$
H_{2}=\frac{T}{T_{0}} \frac{r_{2}}{r_{20}}=\frac{T}{T_{0}} \frac{p_{r 2} / p_{t 12}}{p_{r 20} / p_{t 120}}=\frac{T}{T_{0}} \frac{t_{12}}{t_{120}} \frac{p_{r 2}}{p_{r 20}}=\frac{T}{T_{0}}\left(\frac{Z_{1}+Z_{2}}{Z_{1}+Z_{20}} \frac{Z_{20}}{Z_{2}}\right) \frac{p_{r 2}}{p_{r 20}}
$$

つまり，指腹エコー比 $H_{2}$ は，前述の爪床の影響に，接触時と非接触時における指腹部での干渉波の音圧 $\left(p_{r 2}\right.$, $\left.p_{r 20}\right)$, 言い換えると干渉波の最大振幅 $\left(a_{M}, a_{M 0}\right)$ の影響が重畳された形で表される.

次に，干渉波の最大振幅 $a_{M}$ について考えるが，これには，図 11 に示寸指腹部（半径 $r \cong 7.5 \mathrm{~mm}$ ）での音波の位 相の他に, 図 5 中に示寸超音波照射領域での音圧分布 $w_{\beta}$ が影響しており, 仮定した 2 次元反射モデルの場合, 音 圧の高い探触子音軸上近傍での反射波の振幅が大きく影響する．ここでは，超音波照射領を，前述の図 5 の最大 変位 $(\delta=3 \mathrm{~mm})$ で決まる領域端（図 5 中の $\beta=0, \pi)$ での音圧が，音軸上の音圧の半分まで低下する領域とする. そして，領域内での音圧を以下のようなガウス状の分布で近似する.

$$
w_{\beta}=\mathrm{C} \exp \{-0.28(\beta-\pi / 2)\}
$$


ただし $C$ は， $w_{\beta}$ を $\beta$ について 0 から $\pi$ まで積分した值が 1 となるように定めた係数である.ところで，上記の超 音波照射領域内の各点での，領域端との距離位相 $2 d$ （図 5 に示寸往復伝播距離の差）は，半径 $r$ の円状指腹を仮 定した場合と，半波長の正弦波 $(\beta=0 \sim \pi)$ 指腹を仮定した場合とで，大きな違いは無い.ここでは，後者を採用し， $2 d=2 d_{M} \sin \beta$ とする.

さて，指腹からの反射エコー比 $H_{2}$ は，前述のように，超音波照射領域内の指腹各部から反射する波の干渉によ つて決まると考えられる. 図 11 に示すように， $\beta=0$ の位置を基準 $(\theta=0)$ にして反射波の伝播方向に $\theta$ をとった 場合の，ある $\theta$ での音圧振幅の大きさ $a_{\theta 0}$ は，距離位相 $2 d$ と生体軟組織（音速は約 $1550 \mathrm{~m} / \mathrm{s} ）$ での音波の波長 $\lambda$

（5 MHz 探触子の場合，約 $0.3 \mathrm{~mm} ）$ で決まる位相差を $\emptyset_{\beta 0}=4 \pi d / \lambda$ として，以下のように表される.

$$
\begin{aligned}
a_{\theta 0} & =\left|\int_{0}^{\pi} w_{\beta} \sin \left(\theta+\emptyset_{\beta 0}\right) d \beta\right|=\left|\sin \theta \int_{0}^{\pi} w_{\beta} \cos \emptyset_{\beta 0} d \beta+\cos \theta \int_{0}^{\pi} w_{\beta} \sin \emptyset_{\beta 0} d \beta\right| \\
& =\left|A_{\beta 0} \sin \theta+B_{\beta 0} \cos \theta\right|
\end{aligned}
$$

干渉波の振幅は $\theta$ 方向に変化するが，その最大值は， $\mathrm{d} a_{\theta 0} / \mathrm{d} \theta=0$ となる $\theta_{M 0}=\tan ^{-1}\left(A_{\beta 0} / B_{\beta 0}\right)$ の位置にある. したがっ て, 非接触時の指腹部での干渉波の最大振幅の大きさ $a_{M 0}$ は,

$$
a_{M 0}=\left|\int_{0}^{\pi} w_{\beta} \sin \left(\theta_{M 0}+\emptyset_{\beta 0}\right) d \beta\right|
$$

\section{で与えられる.}

負荷時の干渉波の最大振幅 $a_{M}$ も，指腹と平面の幾何的な干渉を考慮した際の，指腹変位 $\left(\delta=d_{M^{-}} d_{C}:\right.$ ただし $2 d_{C}$ は接触による平坦部の距離位相）に依存した距離位相 $2 d$ により決まる $\emptyset_{\beta}, A_{\beta}, B_{\beta}, \theta_{M}$ を用いて, 同様に求 められる. そして, 負荷時の指腹エコー比は, 爪床部からの音波の透過や，式(7)の音圧比 $p_{r 2} / p_{r 2}$, したがって指 腹部干渉波の最大振幅比 $a_{M} / a_{M 0}$ に依存して変化する.

図 12 は，指腹の変位 $\delta$ に対する指腹エコー比 $H_{2}$ の計算結果である. 図の上部には，図 2 に示した指腹変位で 決まる指荷重 $W$ の値を, 参考のために載せてある. 全体的には, 変位 $\delta$ の増加と共に $H_{2}$ が上昇する傾向にある. このことは, 平面との接触による指腹部の平坦化に伴う, 距離位相 $2 d$ の減少や均一化により, 指腹部から反射寸 る干渉波の振幅が非接触時に比べて増加寸ることを示している. 計算された指腹変位 $\delta$ と $H_{2}$ の関係は, 図 10 に

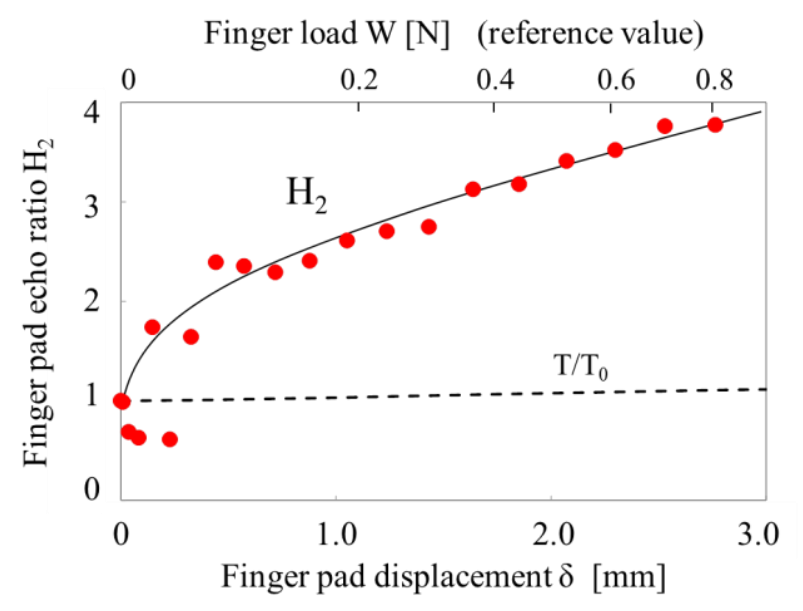

Fig. 12 Relationship between finger pad displacement $\delta$ and finger pad echo ratio $H_{2}$. The $H_{2}$ is increased with increment of displacement $\delta$ because of decrease and homogenization of the phase $2 d$ associated with flattening of finger pad. This calculated relationship between $\delta$ and $\mathrm{H}_{2}$ has the same tendency with the experimental relationship shown in Fig. 10. 


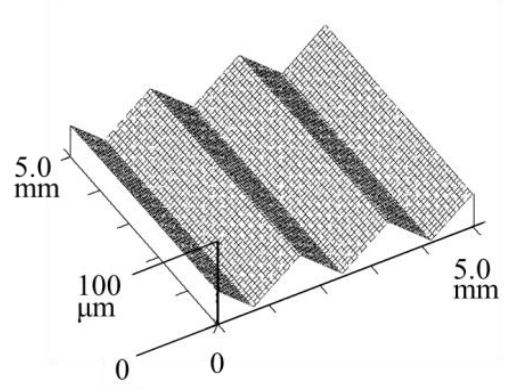

(a) Turning surface $\left(\mathrm{R}_{\mathrm{Z}}=50 \mu \mathrm{m}\right)$

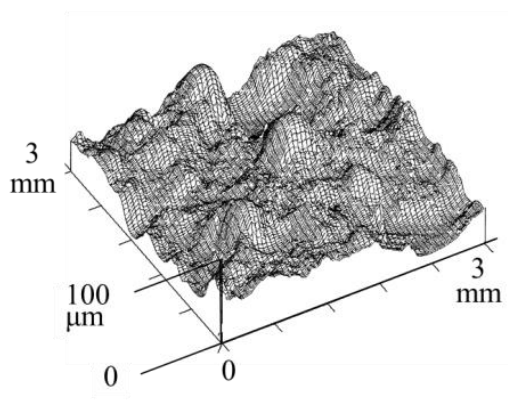

(b) Casting surface $\left(\mathrm{R}_{\mathrm{Z}}=70 \mu \mathrm{m}\right)$

Fig. 13 Surface texture of roughness test piece

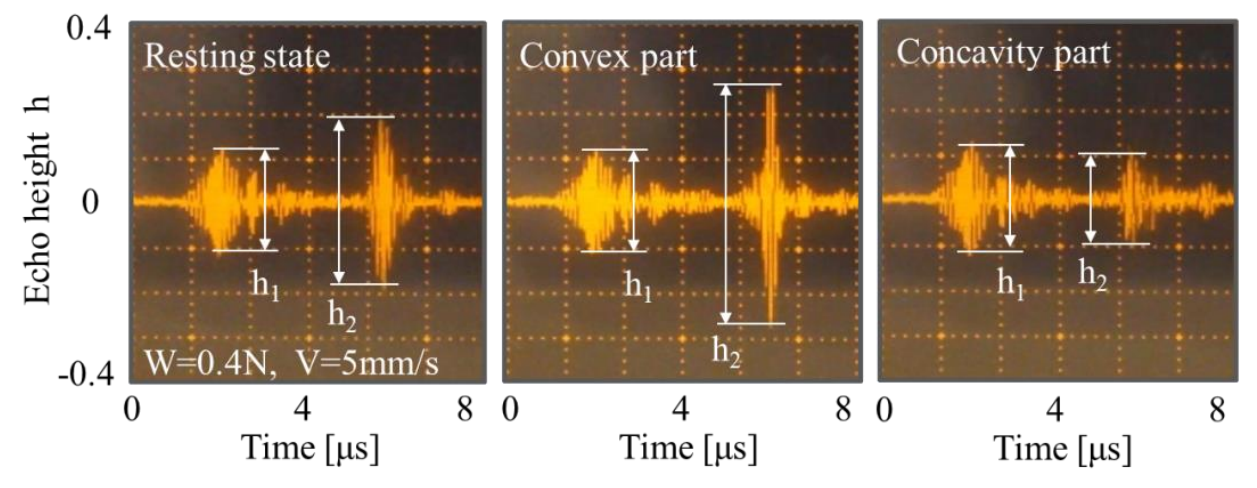

Fig. 14 Observed waveform of $h_{1}$ and $h_{2}$ under sliding speed of about $5 \mathrm{~mm} / \mathrm{s}$ and finger load of about $0.4 \mathrm{~N}$. The simultaneous estimation of the finger load and the surface texture becomes possible, because the finger pad echo $h_{2}$ has large variation whereas nail bed echo height $h_{l}$ hardly varies during the slip.

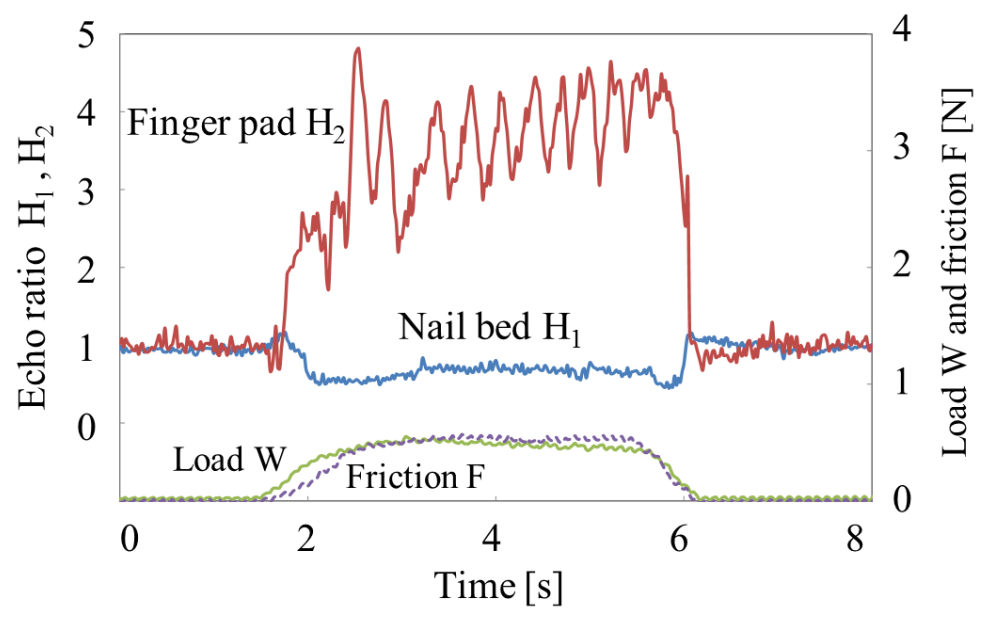

Fig. 15 Behavior of echo ratio $H_{1}$ and $H_{2}$ during slide with contact for turning surface. Nail bed echo ratio $H_{1}$ shows almost constant value $\left(H_{1} \fallingdotseq 0.7\right)$ during action of slide, though surface is corrugated surface of maximum height roughness $50 \mu \mathrm{m}$. Meanwhile, finger pad echo ratio $H_{2}$ fluctuates greatly in response to the period of the roughness pitch. Incidentally, the mean value of $H_{2}(\fallingdotseq 3.5)$ during slide is close to finger pad echo ratio $H_{2}$ at the finger load of $W=0.4 \mathrm{~N}$. 


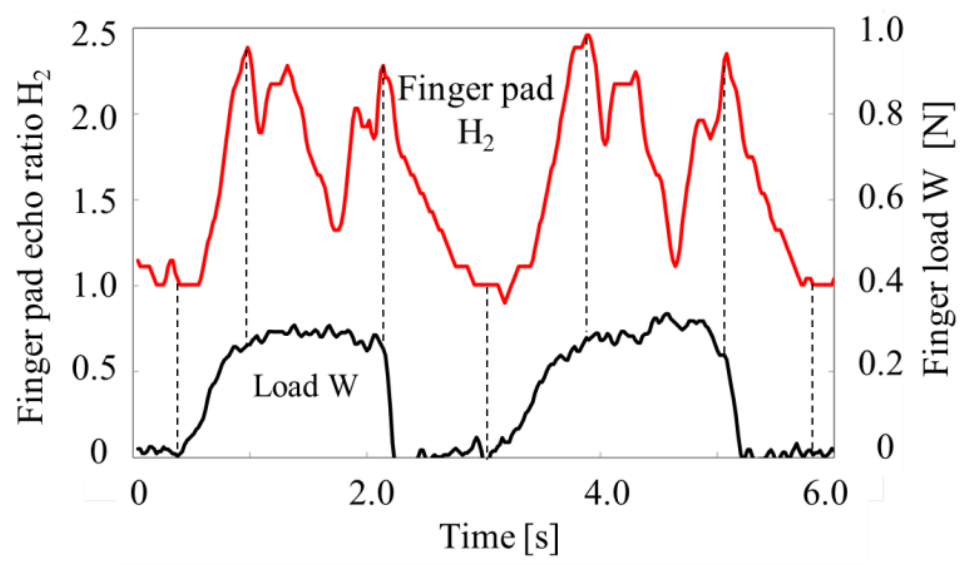

Fig. 16 Variation of echo ratio $H_{2}$ during slide with contact for casting surface. Twice sliding results in almost the same part show agreed behavior, and satisfactory repeatability is confirmed.

示した指荷重 $W$ と $H_{2}$ との実験結果と同じ傾向を示しており，指腹の変位に依存して変化するエコー比 $H_{2}$ にり 指腹荷重 $W$ を推定することの妥当性を確認できる.

\section{6. 指腹エコー比 $H_{2}$ による粗さの検出}

以上述べたように, 爪床エコー比 $H_{l}$, あるいは指腹エコー比 $H_{2}$ によって, 指荷重 $W$ を推定できる. ところで, $\mathrm{H}_{2}$ は指腹変位 $\delta$ に影響されるため, 局所的に指腹の変位が異なる, 例えば図 13 に示した粗さ面上での触動作の 場合，観測される $\mathrm{H}_{2}$ には，指荷重の他に表面性状の影響が現れると考えられる.

約 $0.4 \mathrm{~N}$ の指荷重の下，約 $5 \mathrm{~mm} / \mathrm{s}$ の速度で滑らせた場合の $h_{1}, h_{2}$ の観測波形を図 14 に示寸. 爪床エコーの高 さ $h_{1}$ は，触動作中ほとんど変化しないのに対し，指腹エコー $h_{2}$ は大きく増減している. 図 15 は，図 13(a)の旋削 面に対し, 非接触状態から, 指を接触させ触動作をし, 再び非接触に戻した場合の, エコー比 $H_{1}, H_{2}$ の挙動を 示したものである. また, 同図下部には, 図 4 中の環状動力計により計測された, 指荷重 $W$ と摩擦力 $F$ の挙動を, 併せて示してある. 指荷重は, 指腹接触の初期（指の根本側）に増加し, 指腹中央の接触が継続される触動作中 には，ほぼ一定の值を維持する．爪床エコー比 $H_{l}$ も同様の傾向を示し，最大高さ粗さ $50 \mu \mathrm{m}$ の凹凸面であるに もかかわらず，触動作中はほぼ一定の值 $\left(H_{1} \fallingdotseq 0.7\right)$ を維持する.

これに対し指腹エコー比 $H_{2}$ は, 指腹の局所変形に伴い大きく変動し, その周期は粗さピッチに対応しており, 接触面の表面性状を反映した結果を得ることができている，ちなみに，同時測定された摩擦力 $F$ は，指腹と接触

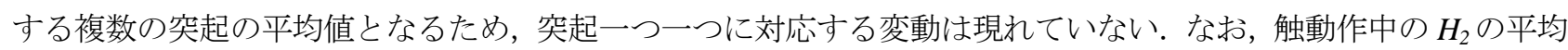
值は約 3.5 であり, これは, $W=0.4 \mathrm{~N}$ の指荷重でのエコー比 $H_{2}$ に近い.

図 16 は，図 13(b)の鋳造面に対する触動作結果（ただし，W $\fallingdotseq 0.3 \mathrm{~N}$ ）である. 旋削面のような $H_{2}$ の周期性は現 れないが，鋳造面のほぼ同じ箇所での 2 回の触動作結果は一致した挙動を示し，良好な再現性が得られている. このように，超音波生体指センサでは，表面性状評価の可能性もまた期待できるが，このことについては，別に 報告する.

\section{7. 結 言}

人の指の爪甲部に設置した超音波センサにより観測される，爪床や指腹部からの反射エコーに着目し，平滑な 平面と指腹とが接触する際の指荷重の測定法や，指腹が接触する面の表面性状評価の可能性について検討し，以 下の結果を得た。

1）負荷時の爪床エコー比 $H_{l}$ は，指荷重 $W$ の増加に伴う爪床部の音響インピーダンス（皮膚剛性に依存）の上 昇により，増荷に伴い減少する．特に，弾性変形が支配的な負荷時のそれらの関係は高い相関を示す. 
2 ）一方，指腹からの反射エコー比 $H_{2}$ は，爪床からのエコー比 $H_{l}$ とは逆に，荷重と共に増加する. この場合の 指腹エコー比 $H_{2}$ と荷重の関係は, 接触による指腹変形に伴う距離位相の減少や, 平坦化に伴う位相の均一化 により，指腹部から反射する干渉波の振幅が非接触時に比べて増加することが主な原因である.

3 ）上記の指腹エコー比 $H_{2}$ は，指腹の局所的な変位の違いに大きく影響されるため，接触相手面の表面性状に依 存した変化を示す.

以上のように，爪床エコー比 $H_{l}$ により，平滑面に限らず，粗さ面との接触であっても，指荷重 $W$ の推定が可 能なこと, 指腹の変位に依存して変化するエコー比 $H_{2}$ により, 接触相手面の表面性状評価ができる可能性がある ことが明らかになった。

\section{文献}

安藤英由樹，渡邊淳司，杉本麻樹，前田太郎，独立成分分析による爪装着型センサの接触力と屈曲の分離，日本 バーチャルリアリティ学会論文誌，Vol. 8, No. 4 (2003), pp. 379-388.

Hyung, K. L., Jaehoon, C., Sun, I.C. and Euisik, Y., Normal and shear force measurement using a flexible polymer tactile sensor with embedded multiple capacitors, IEEE Journal of Microelectromechanical Systems, Vol. 17, No. 4 (2008), pp.934-942.

Kakizawa, M., Nakatani, M., Kawasoe, T., Shiojima, K., Kinoshita, S., Koketsu, K. and Wada, J., Visualizing cosmetic application procedures: A novel tool for universal sharing of professional skills, International Federation of Societies of Cosmetic Chemists, Vol. 16, No. 2 (2013), pp. 101-105.

Kamiyama, K., Mizota, T., Vlack, K., Kajimoto,H., Kawakami, H. and Tachi, S., Applying traction field sensation to robot finger, 1st Joint Eurohaptics Conference and Symposium on Haptic Interfaces for Virtual Environment and Teleoperator Systems (World Haptics), (2005).

小山佳祐, 鈴木陽介, 明愛国, 下条誠, 指先に光学式近接覚センサを備えた多指ハンドによる同時接触での把持（物 体表面の反射率推定とセンサ出力の補正), 日本機械学会論文集, Vol. 82, No.833 (2016), DOI:10.1299/transjsme. 15-00366.

前野隆司，佐藤武彦，爪のひずみを利用した触覚センサ，日本機械学会[No.00-2]ロボティクス・メカトロニクス 講演会, 1A1-69-097 (2000).

Mascaro, S.A. and Asada, H. H., Measurement of finger posture and three-axis fingertip touch force using fingernail sensors, IEEE Transactions on Robotics and Automation, Vol. 20, No. 1 (2004), pp.26-35.

Mukaibo, Y., Shirado, H., Konyo, M. and Maeno, T., Development of a texture sensor emulating the tissue structure and perceptual mechanism of human fingers, Proceedings of IEEE International Conference on Robotics and Automation (2005), pp. 2576-2581.

Nakatani, M., Kawasoe, T., Shiojima, K., Kinoshita, S., Koketsu, K., Wada, J. and Brown, J., Wearable contact force sensor system based on fingerpad deformation, World Haptics Conference 2011 IEEE. (2011), pp. 323-328.

Ohka, M., Kobayashi, H. and Mitsuya, Y., Sensing characteristics of an optical three-axis tactile sensor mounted on a multi-fingered robotic hand, 2005 IEEE/RSJ International Conference on Intelligent Robots and Systems (2005), pp. $493-498$.

Omata, S. and Terunuma, Y., New tactile sensor like the human hand and its applications, Sensors and Actuators A, Vol.35 (1992), pp.9-15.

白井雅憲，多田充徳，高野太刀雄，梅田和昇，爪の歪多情報を用いた指先接触力推定，Proceedings of $2005 \mathrm{JSME}$ Conference on Robotics and Mechatronics Kobe, 1P2-N-093 (2005).

Takeuchi, A., Detection of transferred materials and of flaws under glued steel sheet using tactile sensor, Sensors and Actuators A, Physical Volume 200, 1 October (2013), pp. 147-154.

社団法人 日本非破壊検查協会，非破壊検查技術シリーズ（超音波探傷試験 II）（1990），pp. 93-96.

Timoshenko, S. P. and Goodier, J. N., Theory of Elasticity (Third Edition), McGraw-Hill Kogakusha LTD (1970), pp. 409-414.

Vallbo, A. B. and Johansson, R. S., Properties of cutaneous mechanoreceptors in the human hand related to touch sensation, Human Neurobiology (1984), pp. 3:3-14. 
吉海智晃，但馬竜介，加賀美聡，篠田裕之，稲葉雅幸，井上博允，音響共鳴型テンソルセル触覚センサによる滑 り予知と把持動作への応用，日本ロボット学会誌，Vol. 20, No. 8 (2002),pp. 868-875.

\section{References}

Ando, H., Watanabe, J., Sugimoto, M. and Maeda, T., Separation of contact force and bending of fingernail sensor by independent component analysis, The Virtual Reality Society of Japan, Vol. 8, No. 4 (2003), pp. 379 -388 (in Japanese).

Hyung, K. L., Jaehoon, C., Sun, I.C. and Euisik, Y., Normal and shear force measurement using a flexible polymer tactile sensor with embedded multiple capacitors, IEEE Journal of Microelectromechanical Systems, Vol. 17, No. 4 (2008), pp.934-942.

Kakizawa, M., Nakatani, M., Kawasoe, T., Shiojima, K., Kinoshita, S., Koketsu, K. and Wada, J., Visualizing cosmetic application procedures: A novel tool for universal sharing of professional skills, International Federation of Societies of Cosmetic Chemists, Vol. 16, No. 2 (2013), pp. 101-105.

Kamiyama, K., Mizota, T., Vlack, K., Kajimoto,H., Kawakami, H. and Tachi, S., Applying traction field sensation to robot finger, 1st Joint Eurohaptics Conference and Symposium on Haptic Interfaces for Virtual Environment and Teleoperator Systems (World Haptics), (2005).

Koyama, K., Suzuki, Y., Ming, A. and Shimojo, M., Grasping with contacting each finger simultaneously by the robot hand equipped with optical proximity sensors on fingertips (Estimation of reflectance of the object surface and calibration the sensor output), Transactions of the JSME (in Japanese), Vol.82, No.833 (2016), DOI:10.1299/transjsme. 15-00366.

Maeno, T. and Sato, T., Tactile sensor utilizing strain of nails, Proceedings of JSME The Robotics and Mechatronics Conference, 1A1-69-097 (2000) (in Japanese).

Mascaro, S.A. and Asada, H. H., Measurement of finger posture and three-axis fingertip touch force using fingernail sensors, IEEE Transactions on Robotics and Automation, Vol. 20, No. 1 (2004), pp.26-35.

Mukaibo, Y., Shirado, H., Konyo, M. and Maeno, T., Development of a texture sensor emulating the tissue structure and perceptual mechanism of human fingers, Proceedings of IEEE International Conference on Robotics and Automation (2005), pp. 2576-2581.

Nakatani, M., Kawasoe, T., Shiojima, K., Kinoshita, S., Koketsu, K., Wada, J. and Brown, J., Wearable contact force sensor system based on fingerpad deformation, World Haptics Conference 2011 IEEE. (2011), pp. 323-328.

Ohka, M., Kobayashi, H. and Mitsuya, Y., Sensing characteristics of an optical three-axis tactile sensor mounted on a multi-fingered robotic hand, 2005 IEEE/RSJ International Conference on Intelligent Robots and Systems (2005), pp. $493-498$.

Omata, S. and Terunuma, Y., New tactile sensor like the human hand and its applications, Sensors and Actuators A, Vol.35 (1992), pp.9-15.

Shirai, M., Tada, M., Takano, T. and Umeda, K., Estimation of fingertip contact force using strain of a fingernail, Proceedings of 2005 JSME Conference on Robotics and Mechatronics Kobe, 1P2-N-093 (2005) (in Japanese).

Takeuchi, A., Detection of transferred materials and of flaws under glued steel sheet using tactile sensor, Sensors and Actuators A, Physical Volume 200, 1 October (2013), pp. 147-154.

The Japanese Society for Non-Destructive Inspection, The NDE technique series (Ultrasonic flaw detection II) (1990), pp. 93-96 (in Japanese).

Timoshenko, S. P. and Goodier, J. N., Theory of Elasticity (Third Edition), McGraw-Hill Kogakusha LTD (1970), pp. 409-414.

Vallbo, A. B. and Johansson, R. S., Properties of cutaneous mechanoreceptors in the human hand related to touch sensation, Human Neurobiology (1984), pp. 3:3-14.

Yoshikai,T., Tajima, R., Kagami, S., Shinoda, H., Inaba, M. and Inoue, H., Slip detecting by tactile sensor using Acoustic Resonant Tensor Cell and its application for grasping, Journal of the robotics society of japan, Vol. 20, No. 8 (2002), pp. 868-875 (in Japanese). 